\title{
Heporter on
}

\section{Hornt to Coppar Corporation Lioltad}

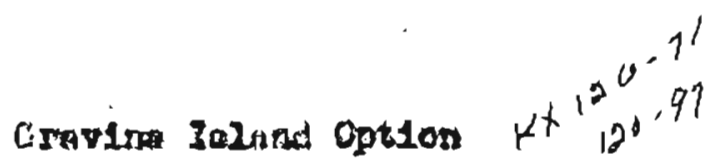

Southagtarn Maska

\author{
and \\ Lafletno and Learoolzea Tornshtpe ropurty
}

Iorthwostom quabeo

by

Alan C. La, P. Pne

Movabor 23, 1956. 


\section{IN $D \&$}

Prive

Cert1flouta - Alan C. Lao

Letter ro - Gravina Proparty Plans

Seport on Grevina Ialnad option

$1-15$

Maport on Laketno and Demelodzas

16

Plan of Gravino elalsa group - In pescicot

Plan of craving drili holen - in goeket 
Horntt Copper Corporation Lialtor, 2L Cambio Stroet, Bast, ROUYH, wubleo.

I. ALAr C. LBfy of the C1ty of Norundy, in the Provinoe of lugbeo, do borwby oartify that

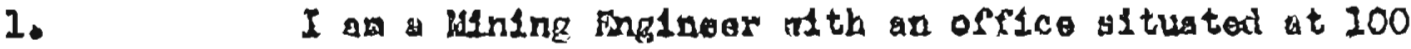
PIfth Strot, Norandt, kunboo.

2. I am a graduate of the Univarsity of Toronto in IIIning

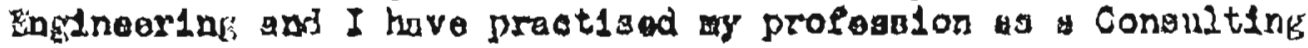
Enkinoor for over 20 yeare.

3. I hava no lnternet in tha oecuritias of this Corporation or In any of the ololma orned or optloned by 1 t, nor do I expect to have any.

4. Hy saport datna Novamon 13 th, 1956, 19 based upon peraonal vilits: to tho proporty on April 18th, 1956, and Cototar 8th arri 9th.

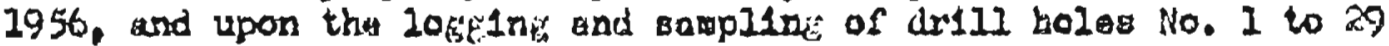
Inelualve done under the suporvialon of J. Jewoll, Mining ooologlnt, rosidart at the property wh1le tho wark was belng onsried out. $n$ sumetury of those resulte forme part of thin roport.

DAT th this 13th day of Novomber, 1956

NCisindi, Cuebeo.
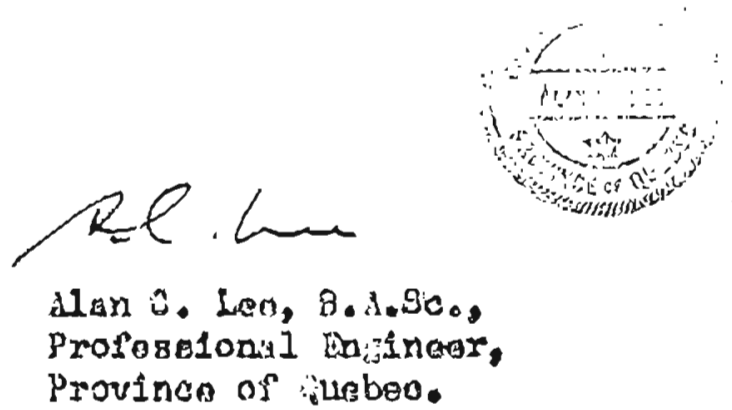
Hovenber $23,2936$.

Bornt to Dapper Carporation Llastod, 34 Ganbla itrat, East, ROUTH, Quabeo.

Desr 31rs:

Hinz Proparty Plano

The pland which accopany the Faport on the cirolins Igland Option conglat ofs

1. Location wap ahowing alatm groups, atoh $2^{4}$ to 2000 .

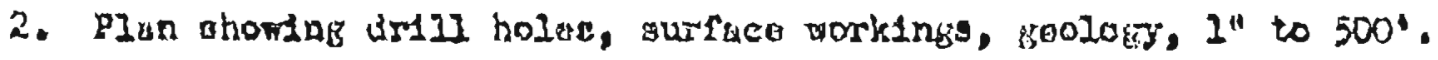

Tho Plret plan to largaly dagramatic boouse in Mlabka it

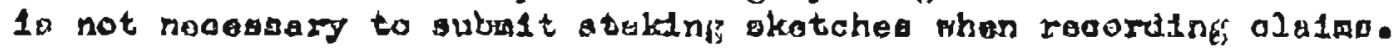

The socond plan ras drapn by J. P. Jawell, Eoologlst, who ves in oharge of the rork at the proparty for 1to duration in 1956. Th1s outIInas tho Hain Paula group, the North Paula and thi Victory Hintne

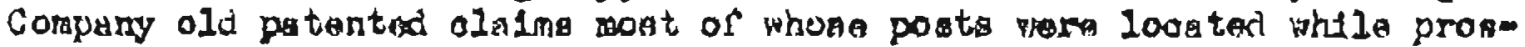
poctine. The property mas not reolocically mapped andaly beanuse of the scaralty of rock outorop inland from the seacoset. This plun is rearonably gocurate in showing the rolidionahip of ahowings and drill hole ralotive to the property houndarlae.

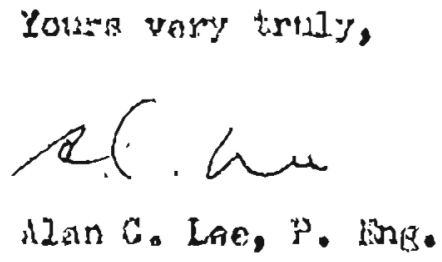




\author{
Alun C. Lee, P. The. \\ Report on \\ Boratto Coppor Corporation Lla1tod Option \\ Gravina Island \\ South-katern ilaska \\ U.S.A.
}

Novorser 13, 1936.

\title{
Introxinetion
}

Borndta Copper Corporation Linstad oms or bas undor option I26 olaima, nominaliy 20 soma okoh in four groupa:

$\begin{array}{ll}\text { Pauja } & 47 \text { oluino } \\ \text { Dear } & 44 \text { alalios } \\ \text { Salt Chuck } & 12 \text { aluinis } \\ \text { K1tz } & \frac{2}{125} \text { cluiatis }\end{array}$

It 111 be noted that 56 alains have boan adued to the eroup dosarlbed in ay rnport of Apr11 21, 1956. Th1s bae done in order to of foris protootion for cortaln ohoulngs and disooverlos at tho north ond of the property whloh thls ausmor's prospocting had looktad.

Sinoe hprli 19th th1s year and up until ootobar 13th tro, snd for a short porlod, thieg ditwone ar1120 boloniting to bloglos Brothors limited

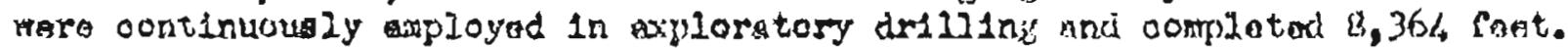

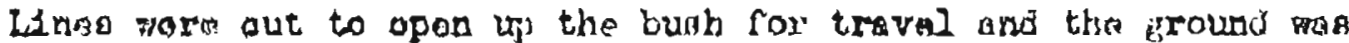

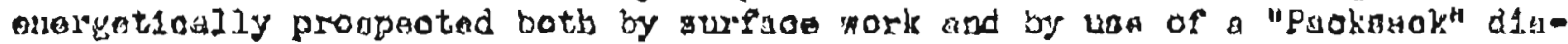
wond dr111 purohased by the Corporation.

Proparty

This congigte of the folloning loce clatrae ratelotered at the

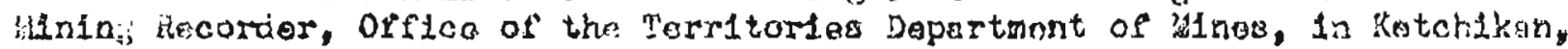
ilaska.

$$
\begin{aligned}
& \text { Paula Group } \quad \text { Nos. I to } 53 \text { Irolugivo axoopt } 17,34,37,39, \\
& \text { 41, } 19,50,51,52,53 \text {, 4nal } 54 \text {. } \\
& \text { Bear Croup a Nor. } 1 \text { to he Inolualve. } \\
& \text { Siglt Chuck Croup - Nop. I to 2\% Laclug1ve. } \\
& \text { K1iz jroup - Nog. } 1 \text { and } 2 .
\end{aligned}
$$


The north part of the Paula group and K1ta No. 1 and 2 gdjoin and posolibly overlso old patented olrims whlah belonged to the Vlotory Mlning

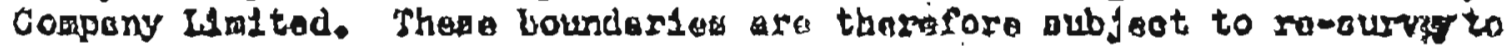
vecurataly doflne the IIntta of lorndtelg ontion. The Viotory lining

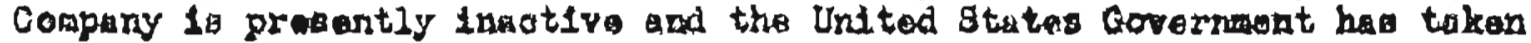
steps to ragain titio to tha property, hovevar thoir ropregentatikns havo

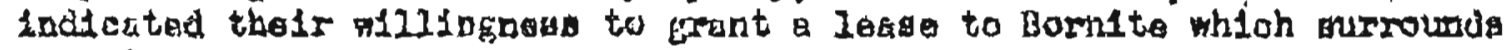
tho older property.

Those clatino aro otriked in one oontinuous blook, excopt for the

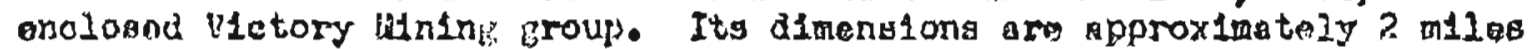
wide of 2 alles lonfi from nouth to noutb.

It Ilon long the gat shore of Grovina Ioluno facing Hacholo

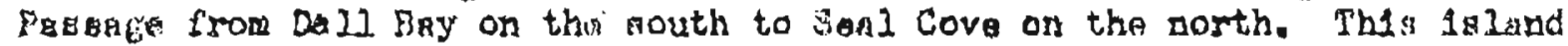

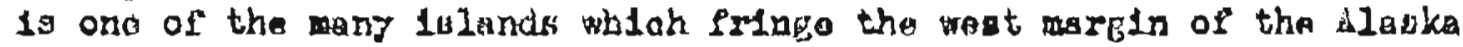
Panhandle and it $110 \mathrm{~g} 10 \mathrm{milas}$ south of the buatilnit tom of Katohikan. It is about the seme diatenoo northwos of Annatte Island Alrport whiob 15 landing Mald for thet area ani is a rogular port of ould for alrilners

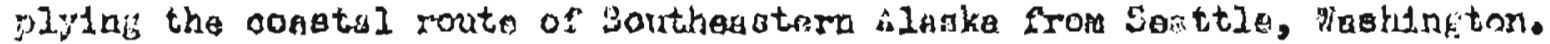

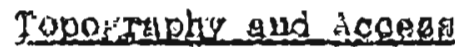

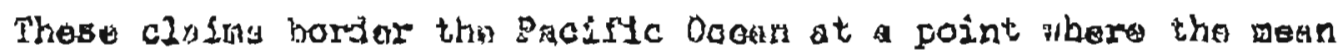
ranis of tides 10 about 15 foet from low to hligh water. The coastilne is Ia1riy seop and rooky but sheltar for landing supplias at Dall Bay Is afforded by lalande und reof 3 towerde tho acouth. At Seal Cove good aholtar is provided from tho oouth by ros at low water, hut oouthwest galas pound the shore uniserclfully at high tide.

Iforever, tupulsas may bo Ianded in pood meather frot shallom draft boate and doeplenos at ylmogt any stage of water. Both araft ara plontiful for hiro at Ketchikar frow whioh it is les than 15 minute by alr.

The ground rises falrly rapldiy from ticiowater to a moximum

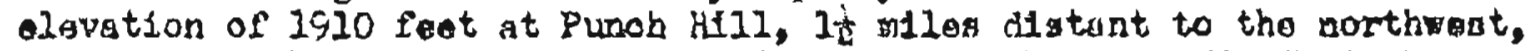
fast beyond the property. Wogt of 1 t would not be over 500 foet atrove

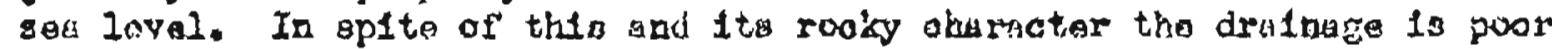

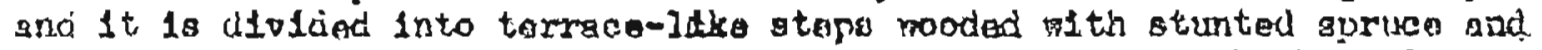
I1'. Wach terrace is covernd with labracios ten and nosa shioh ancloge gutall ponds and musker arraz. Here and thars rocky spurs and knolle profeot throuph the musikog shioh on bo prospeated.

\section{Ceojogy}

The socks of cravlna Is land heve bean desoribed by thoodor chopin in Profoasional Pagar $120 \mathrm{D}$ of tha U.S.Q.S. (Wopnrtaont of Interlor)

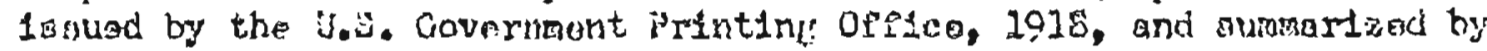
the uniaristund as follors

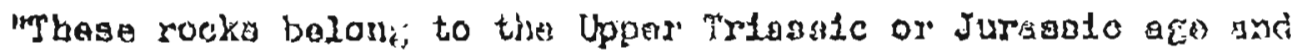

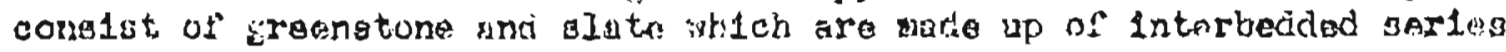


of alterad tupfa, Fow and black slatos w1 th some Intrualvor, oocurxing

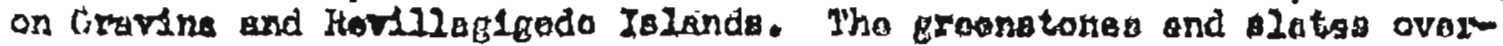
If the Upper TFlando rocks rf.th apparent oonformity. They oooupy inios parallel belisa on Cruvina Ioland, one from South Vallonar Polnt to

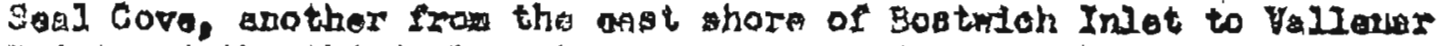
Polnt and tho third along Tongags Rarroks from OId Indian tom to Gravina Point.

"Tho rocka consigt of voleanic breothas and tuffe olth intar-

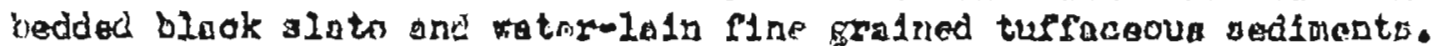

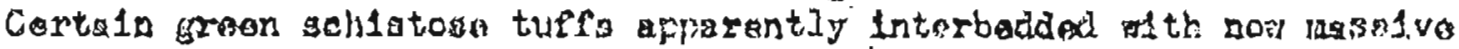

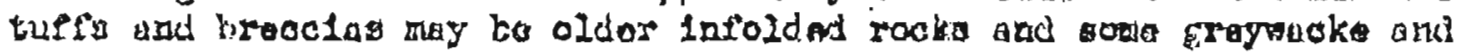
alates may be younger irfolded rocks."

"The voleanio rocke my be dividad up as pollowat

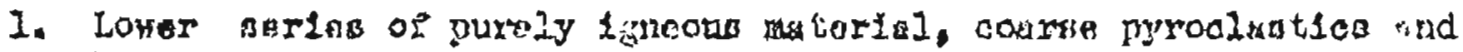
breocia.

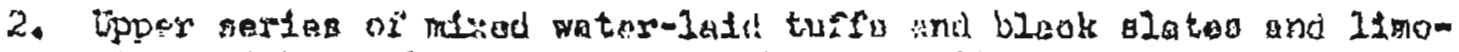
atone with purphyitio baslo rooks of glallar aomposition ovichatiy partly intrusivo and partidy explosive."

* No oharg IIno separatos the two parta. Tho black slates

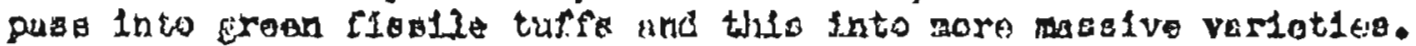
The IImastone badied are too 11 to bo bhom on asp."

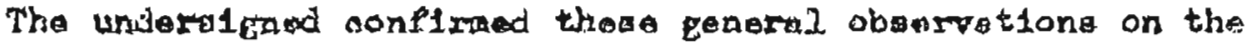

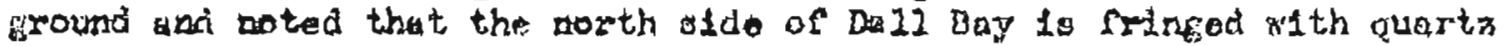

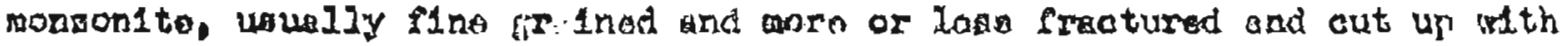
quartz-cerbonate atockrorke. The sawa intrundve monzondto nos noted on

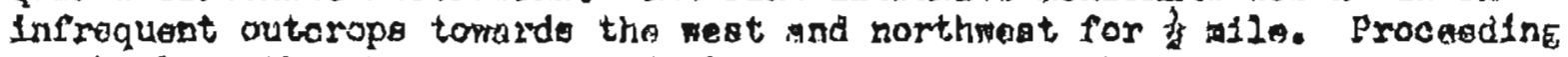
north blone the abore towards Senl Cove there is a ohange to ereonstone. st of noar thig contact tho 18 a srecesated zono shich oonetitutas the mein ghowne at Dall. Hay milch was exploted by drill holar Ho. I to 13 Incluselvo.

Chaloopyrits inerallzation 1s conoontratod where tho manonita Intrusions have been sosompentied or followad by brocelating notion with

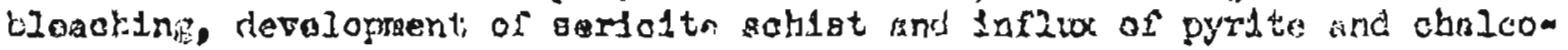
priste minerallation. this is in the form of hery to asasive narrom bands

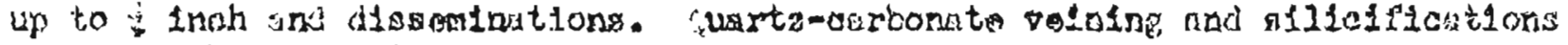
ritaceded tise minorriluation.

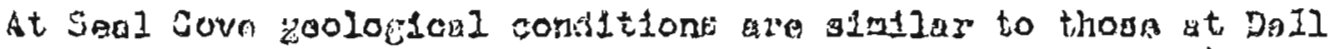

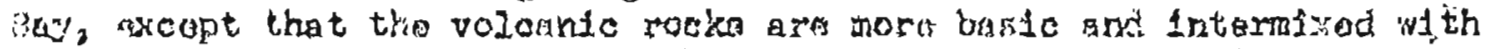

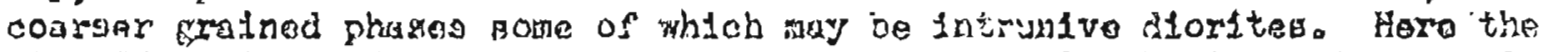

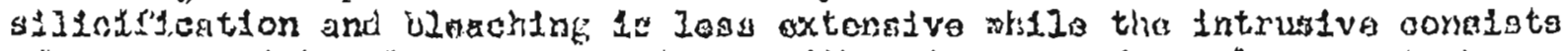

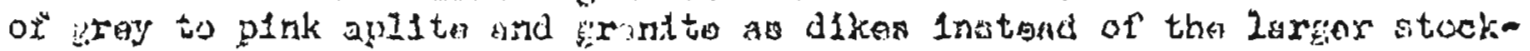

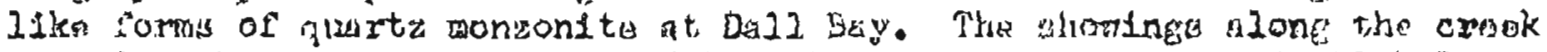
ontering the northwest cormer of 3 en 1 Covo mer: axplored hy dr112 boleg $15,21,20,21,22,23,24,25,26,27,29$.

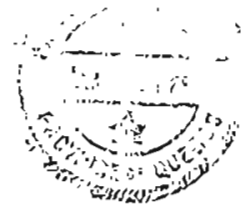




\section{Shompara end Higtory}

According to old U.S. Covostmont roporta coppar mos plrst

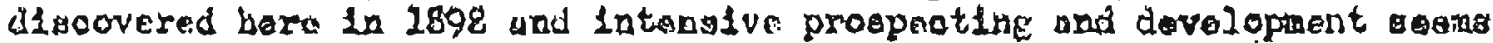
to havo gone on for aeveril yeare to be followed by qulot periode up to

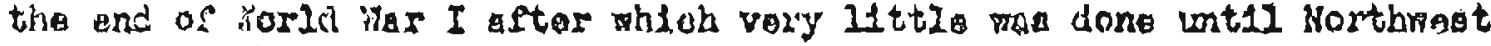
Vontured talend tho property in 1954.

One report by Alpred Huise Brooks in 2902 desoribes the operationg In tho Ketohikan Uluing Dlatriot when they wose at the poak of thnis aptivity. Thooe ground Dall bey are a follows:

"Rosulund and Door Park Mlning Company - the olkisa balonginet सX120.30

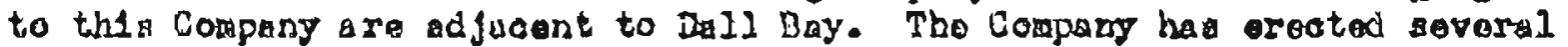

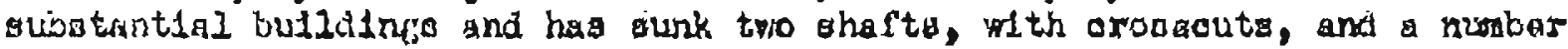
of teet plte. The tro shefte ato In the Bouthern cornar of Dall No. bo

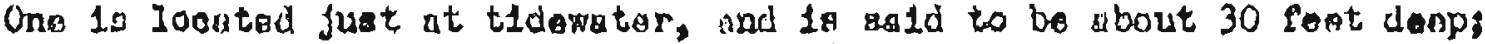
this other to 20 foot hilher, and 50 or 60 roet deop with a croveout at

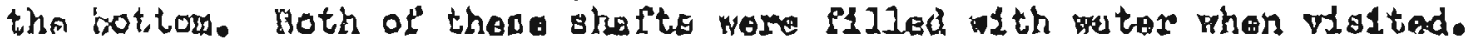
The doeper ahelt 19 provlded with a gtaur halst. The oro obsorved on

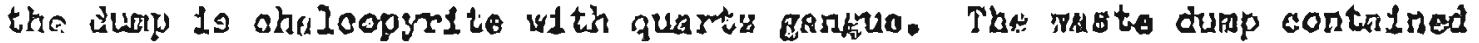

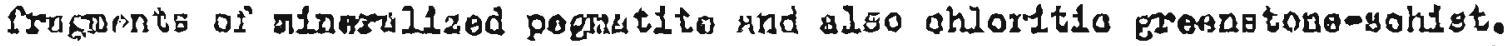
dbout 50 reat to the eat of the shaft is an outerop of brecciated porphyry."

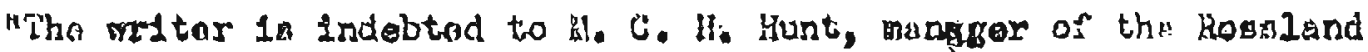
and Daer lark gandne Coupany, for the followints informition, which is

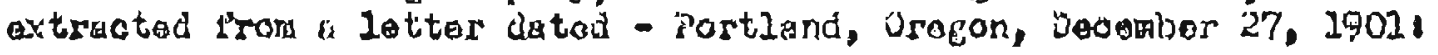

"I regrot that no one represonting the intarest of the eompany wis on the pround at the ties of your oist, as the rasl woritia of the property could bo thosn only by one fandlifar altb the ground, to polnt out

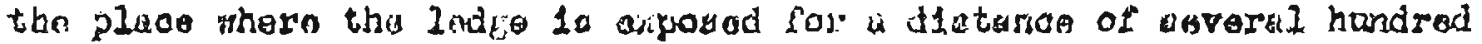

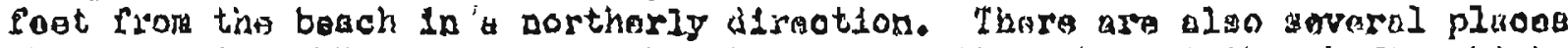

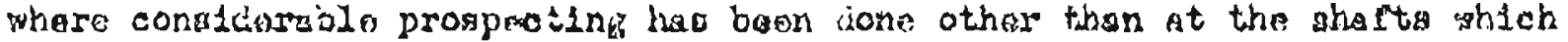
you visitad. At all the pointa whom prospocting bas been done on chis

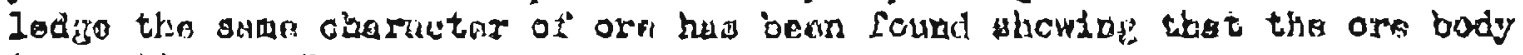
13 continuous."

HFrom the many assays nodo from tino to time, values rers shown In gold, coppar and silvor, fluoturting sometimes us bich ns 305 oopper,

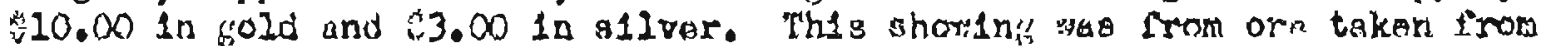

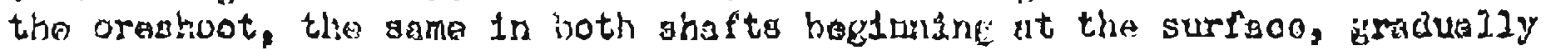

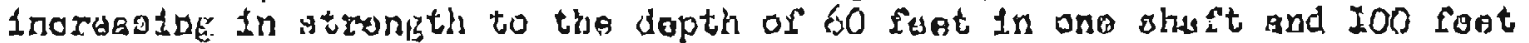
In assothur. In the latter a orossout ma run et depth of 90 fees a

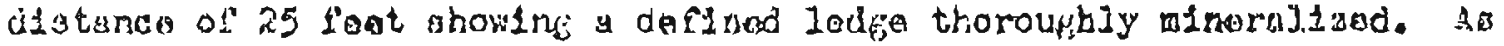

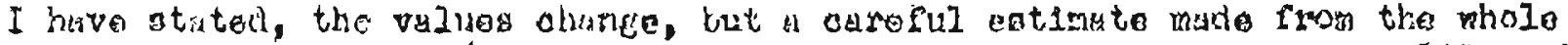

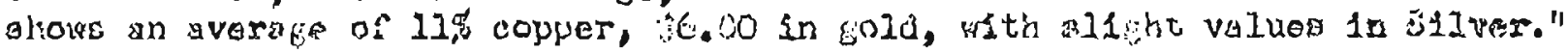

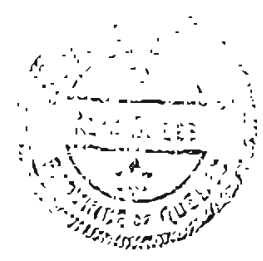


"Apax Group - this eroup, mbraolnte shout a dozen cla1m, 1160 a 113 to the north of Dall Bay. The hleheat is on the top of the mountain. 1,000 Peet above tidewater. The ore bodlea oontain ohelcopyrito nth zino blende, ama ofton carry golit values."

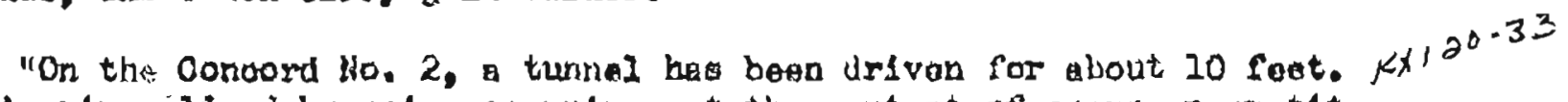

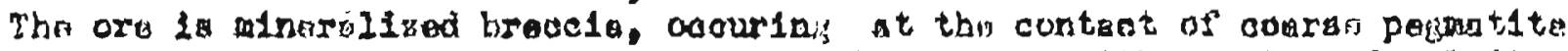

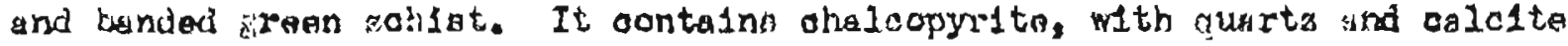
Bangere und $A$ ilttio toingureze."

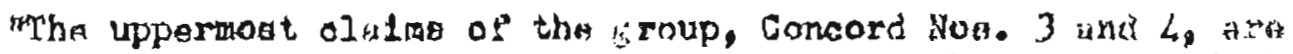
neas the top of the mountrin. Then cioponitg lia ot tha contret of the

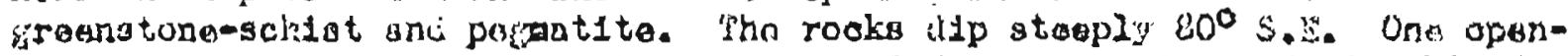

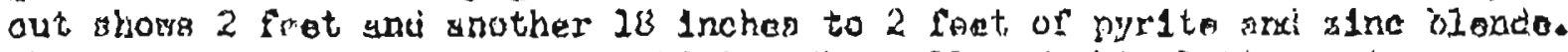
"he volns out the sirnengtong-sohlat. Ithe wally of this latter vein aro glisis:10d."

non the gluo Ity clalm of this roup a turnel hag boen driven about $K \times 120-91$ 50 fat. The tunnel intargocts some brecclatod zonne near the contercts

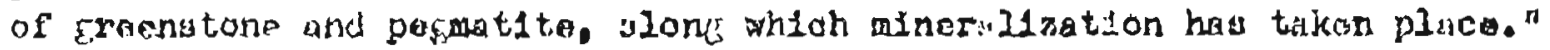

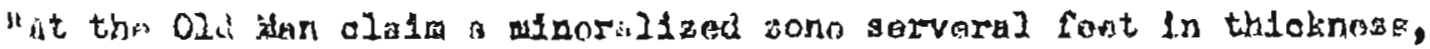

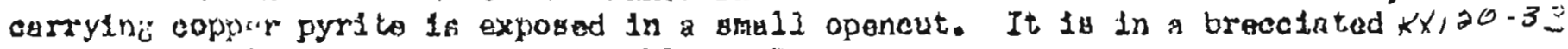
sone and ourrieg consluerabl! alno blente."

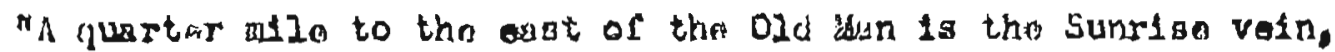
shioh has a thloknops of 12 to 16 1nchos. It has boon trmood on the 1 urfaoe

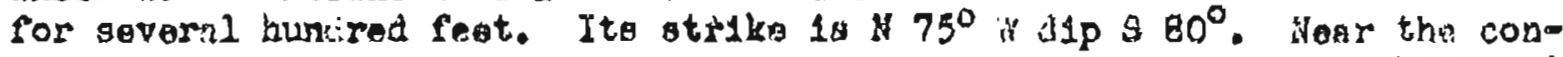

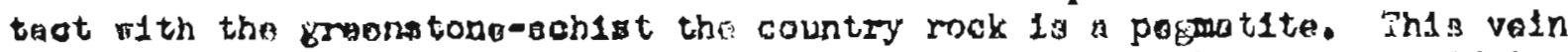
aeem to be betar ceflned then many of the othors, and ghoer a beatirul

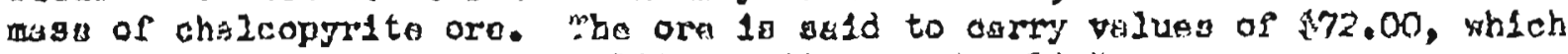
is chlafly in aopper, fith a Ilttia alluer and gold."

"Grenadier olaim - this propirty is located ubout I nile poot of the upper and or Dall 3uy. A proipuoting sut bout 10 foet deop shone

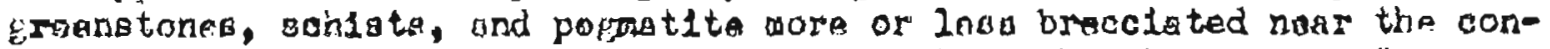
tuot. Some rimar:11zution has taken plece aloni: tho strear zonos."

"At, 3001 Cove in the northarn past of tha clatug axplorad, the

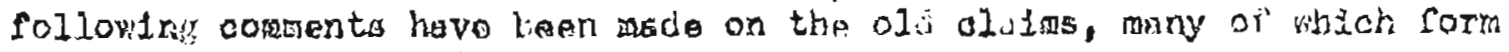
purt ot the Vlotory istain: Company:

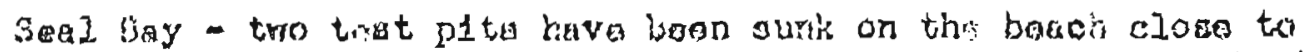

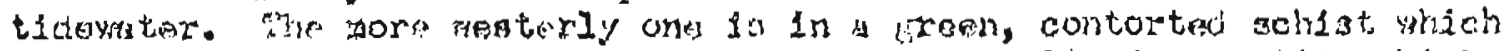

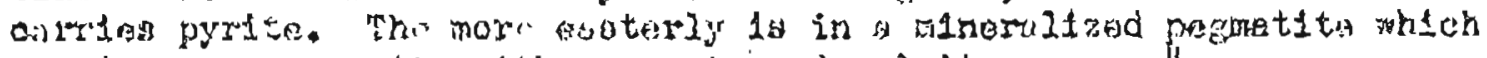

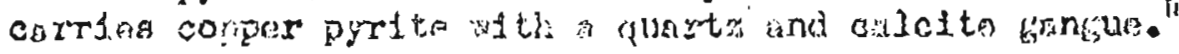




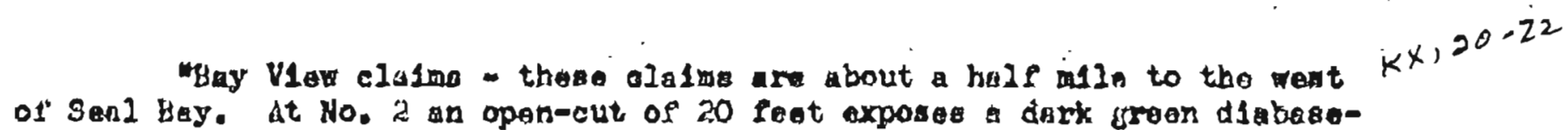

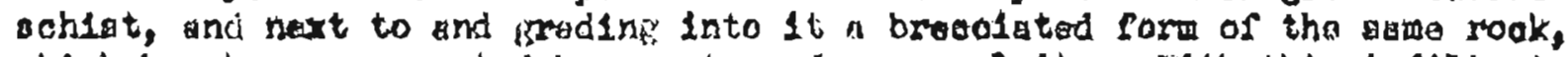

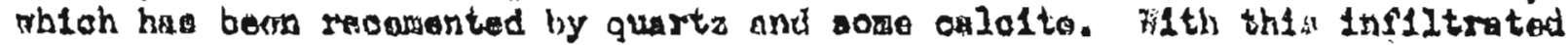
quarta orcur Iron and copper pyrite and some borntto. The mineraligation ocoura at Intorvala for 30 to 40 feat. at tho No. 3 claim of this rroup thare

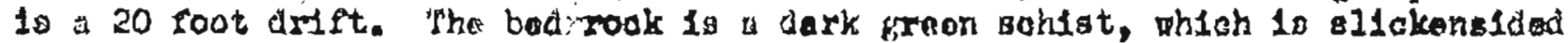

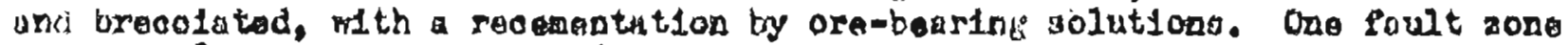

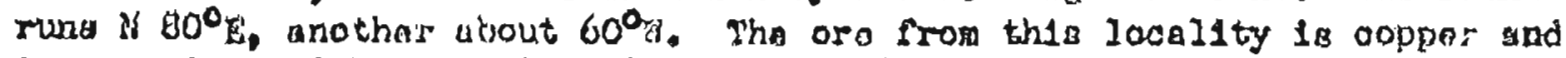
1ron pyrito, with rome aine blonde. The drift sas driven alone valn oarrying

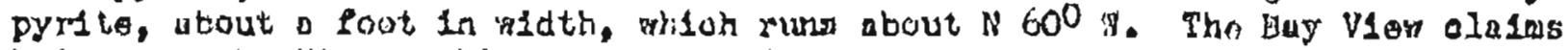

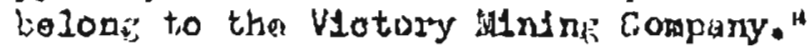

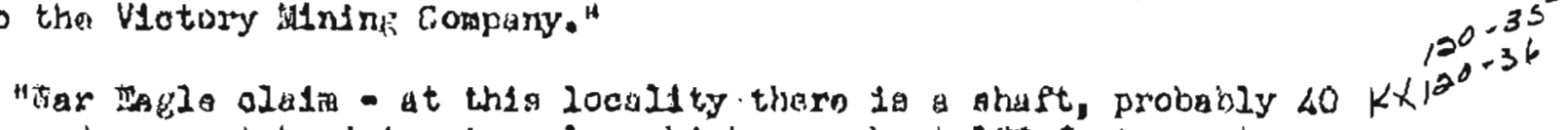

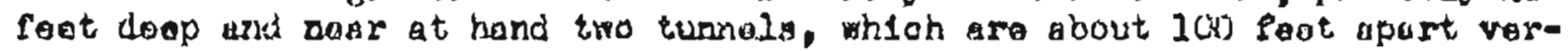

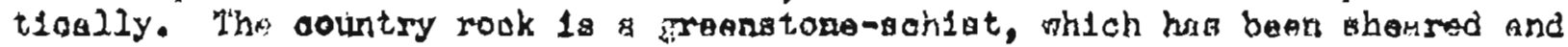
trocelated, and the ore ocours along the shan zone. Hear the brosat of the lover tunnol about 3 fret of the breisoln anci ore are nhom. "she striko of

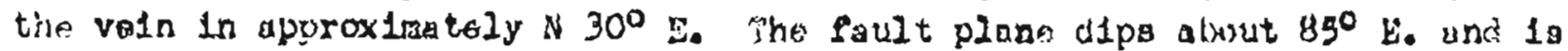
apuroximately paraliol to the atrike. The oro is a chalcopyrito and 1a sald to ourry iolo valuas. This cluin, together with tha 518 Joe, whare an opesout axposes the extarision of the same riloeral-basting zono, balonis to tha Patternon Compary. Iho semr company also owns the Hobo olain rhioh Joins the "ior endo on tho most. The lattor res not vistod."

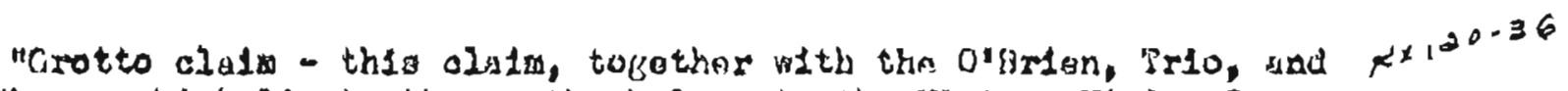

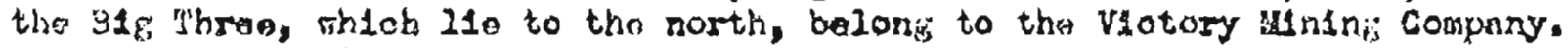
Then the cxamisation nas ade there mas no ona on the property, but since thon devalopmonts have bann setively pissind."

"The wine rorkings rore foum to ounsist of a timnel hbout 100 feet Ionf, 10cated about 600 fent above tide, and aeoond tunriel, 50 foet higher and 30 foet long. The lorer tunnel cuts aerose the rollation of tbe prennstone-

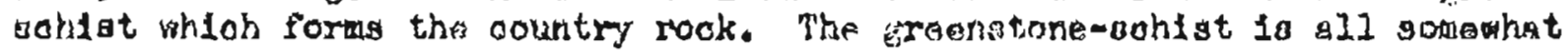

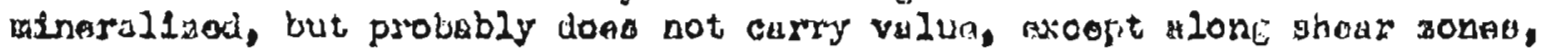
wher the mimarilization has beon morn Iatonse. These ghonr zones oosur at Irongular intarvalg in the 1tuar 30 feat of the tinnal, which is near a mags of Intruglve poematito. The uppar tumnol has panatroted a brecclatec sraan-

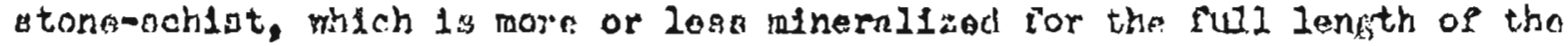
tumsel, or shout 30 root.

"Sinoo our axulination the lower tunnel hila beon siven 100 fagt

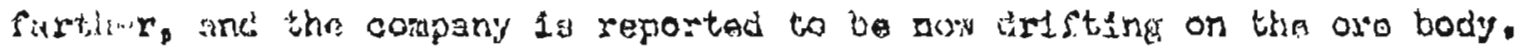

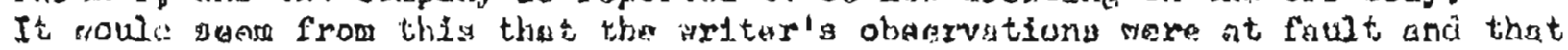

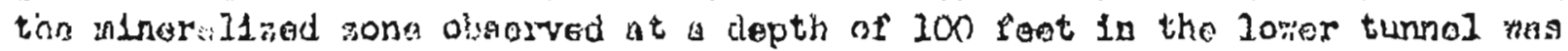
not the onde ore hody which in sxposed in the uppor tunnol. The oompany

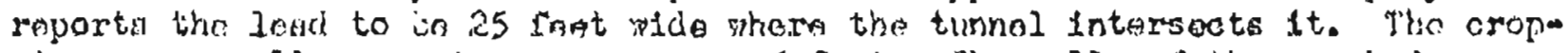
ping averige il peroent copier seroen 5 feat. Whe wulja ol tha ore body

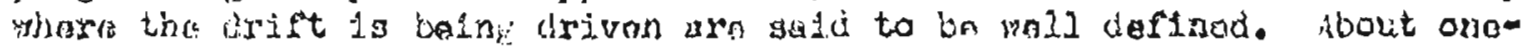
Courth of a mile in a northerly ulpetion from the lower tunnal a small giveft,

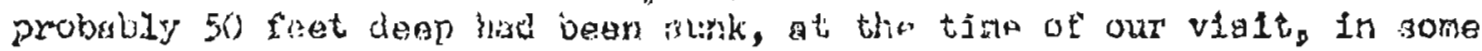
alnorstzod soliste." 


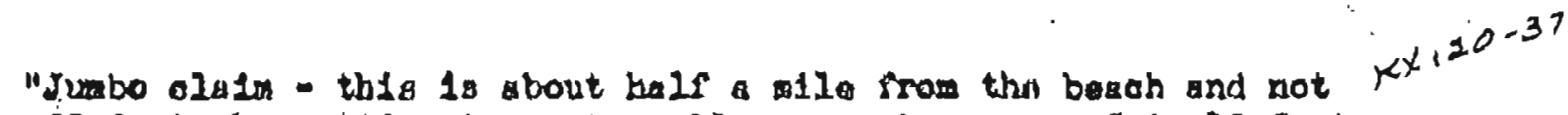
more than 50 feet above t1damater. A smil orosacut oxposes 5 to 10 loet of a sone in part heavily minertilsed with coppor and Iron pyrite. In 1 ta

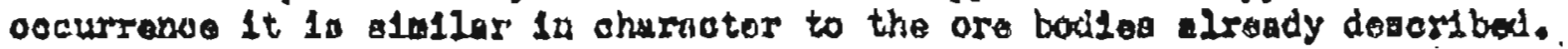
The opantag is in a flat, axd thare are no outoropg in tho vioinity.".

this report.

This is all tho gigniflasat hiatory avaliablo at the time of writing

Th1d old data hag Ifteta prasant-day labortance except to show the wisepread neture of the oppper occurronoas and that they wore intarosting

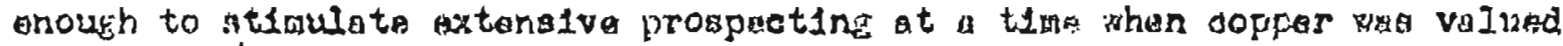
at about $1 / 5$ ita provent price.

\section{9moni Dr11310:}

Since the report by the undera1gnesd, datad apr11 21st, 1956 Diamond drtiling twa bem oarriod out in the lall Bay area for a distance

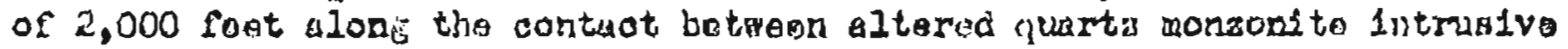

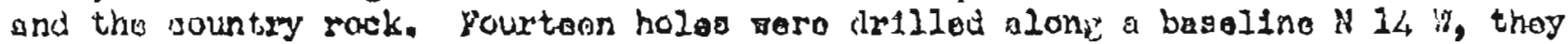
wern mukered $1,2,2,3,3,4,5,6,7,8,9,10,11,22$, and 13, n totol of 3,934 feat. Coppar valuea raja conilnad to the jerst 8 holes or tho noot southerly 600 goot, as Poliown

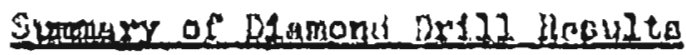

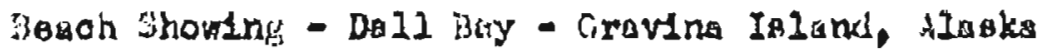

Basolino $\mathrm{A}^{*}$

Logrtion

Holo No. 1

Prom $\quad$ To

\$ L Lost

DIp A's Length

$N=0$ pluz 20

$102.0 \quad 107.0$

(100

iildth

Coro

DAB.

Leng.

E $250^{\circ}$

$10 \% .0 \quad 109.0$

$109.0 \quad 120.0$

1.00

$5.0^{1}$

86.91

$46^{\circ}$

$254^{\circ}$

$310^{\prime}$

dvarige

\subsection{5}

2.0

$\frac{0.30}{0.52}$

12.0

or

$28 \%$

Hole $\mathrm{NO}_{4} \mathrm{Z}$

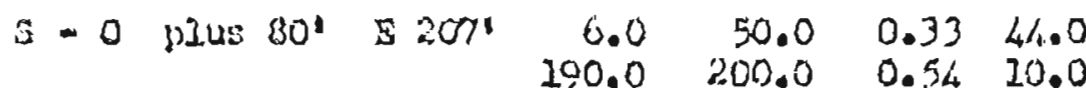

$50 \quad 26 \pm$

264 
Banolla "A"

ioontion.

Holn No. 2S

Shane as No. 2

on surne saction

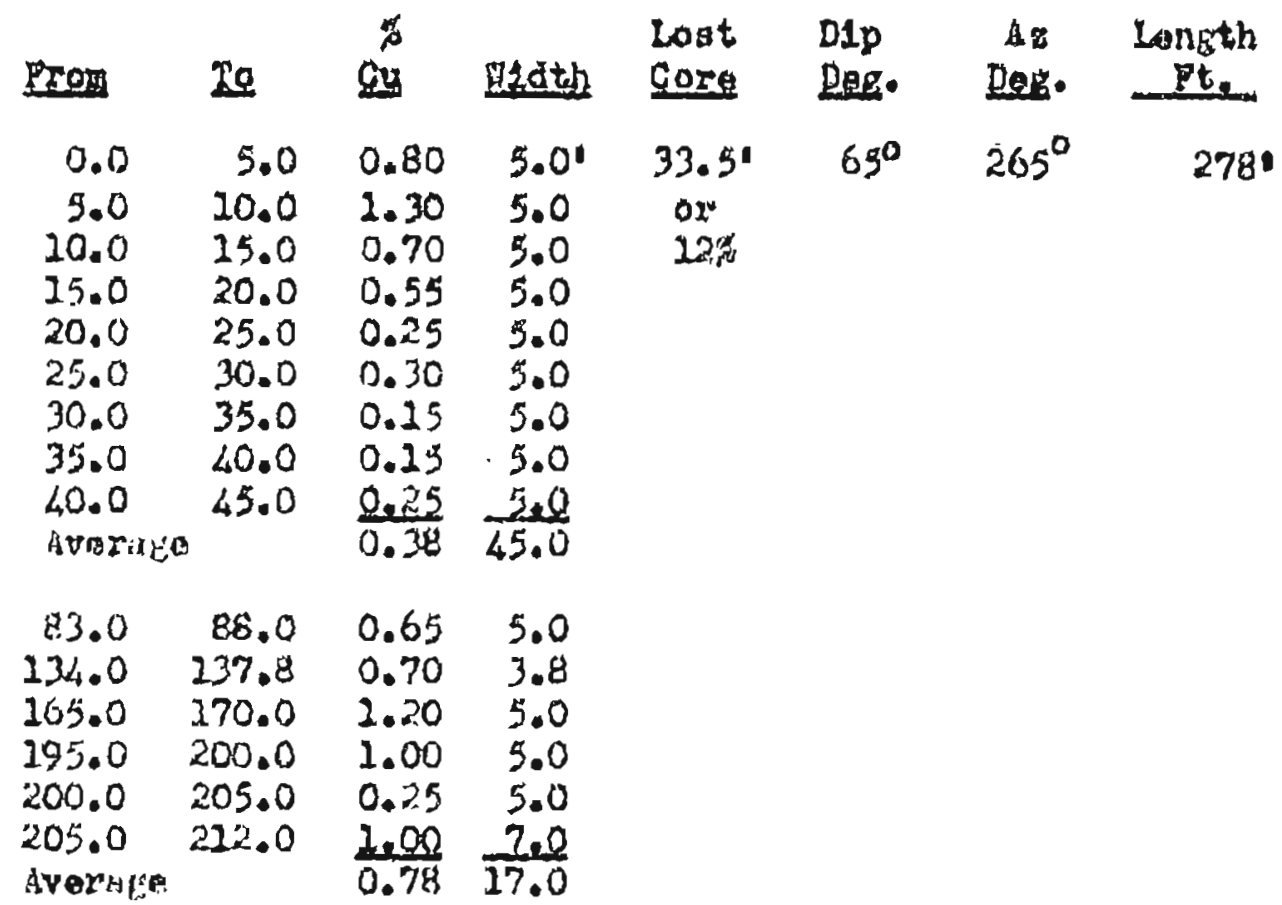

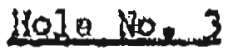

s - O plues 358 $1351 \quad 1.1 \quad 75.0$ Avarage

$0.47 \quad 73.9$

$20.0 \quad 40$

74.

240

$11 \%$

Holo No, 4

$N-2$ pluz 9013225

$$
\begin{aligned}
& 220.0 \quad 225.0 \\
& 228.0 \quad 233.0 \\
& \text { dvaruge } \\
& 0.65 \quad 5.0 \\
& 12.5 \\
& \text { or } \\
& 0.83 \quad 13.0 \\
& 45 \\
& 2.54 \\
& \begin{array}{llll}
335.0 & 340.0 & 0.55 & 5.0 \\
340.0 & 345.0 & 0.05 & 5.0 \\
347.0 & 353.7 & 0.65 & \frac{6.7}{18.7} \\
\text { Av. } 200 & & 0.39 &
\end{array}
\end{aligned}
$$

\begin{tabular}{|c|c|c|c|c|c|c|c|c|}
\hline $3-0$ plun 2301 [i 230 & $\begin{array}{r}5.0 \\
10.0 \\
20.0 \\
25.0 \\
30.0 \\
3 v 3 r=9\end{array}$ & $\begin{array}{l}10.0 \\
20.0 \\
25.0 \\
30.0 \\
35.0\end{array}$ & $\begin{array}{l}0.25 \\
0.65 \\
0.25 \\
0.25 \\
0.70 \\
0.60\end{array}$ & $\begin{array}{r}5.0 \\
10.0 \\
5.0 \\
5.0 \\
5.0 \\
30.0\end{array}$ & $\begin{array}{c}45.0 \\
\text { or } \\
15\end{array}$ & 4 & 220 & 306 \\
\hline
\end{tabular}$$
390
$$

Iloze: No, 5

Hol 150.5

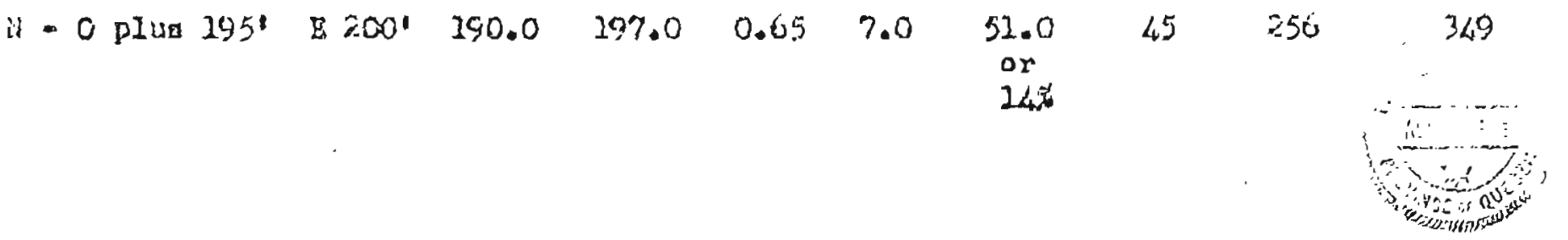


Bagel1ne " $h^{n}$

Loortton.

Bole No. 7

ton

Inom To G Midth Cora

Despo

Agr. Lanpth

S - 0 plue 50 F 90

$60.0 \quad 60.0 \quad 0.65 \quad 0.0$

$31.0^{\prime}$

$70^{\circ}$

$76^{\circ}$

2921

$\begin{array}{llll}135.0 & 140.0 & 1.10 & 5.0\end{array}$

or

$\begin{array}{lllll}157.5 & 162.5 & 0.45 & 5.0 \quad 11 \%\end{array}$

$\begin{array}{llll}180.0 & 190.0 & 0.10 & 10.0\end{array}$

Holo No, 0

N-O plus 390' E 135' no sampling

18.0
$0 \%$
$6 \%$

324

Holet №s 2

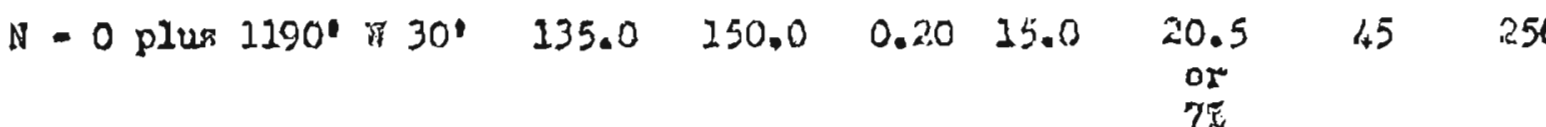

256

214

N- O plus $760 \quad \pi 30^{\circ}$ no sampling

Holo 110.12

औ. O plus 1030 ' 65 ' no sampling

$21.01 \quad 45 \quad 256$
or
108

Bola 10.22

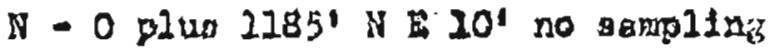

4576

Yolde No, 23

is - 0 plus $1790^{\circ}$ if 15 , no aumpling

$\operatorname{Tot} 15$

$50 \quad 256$

Tho outstandine' regults may ba rastated at followg from abovet

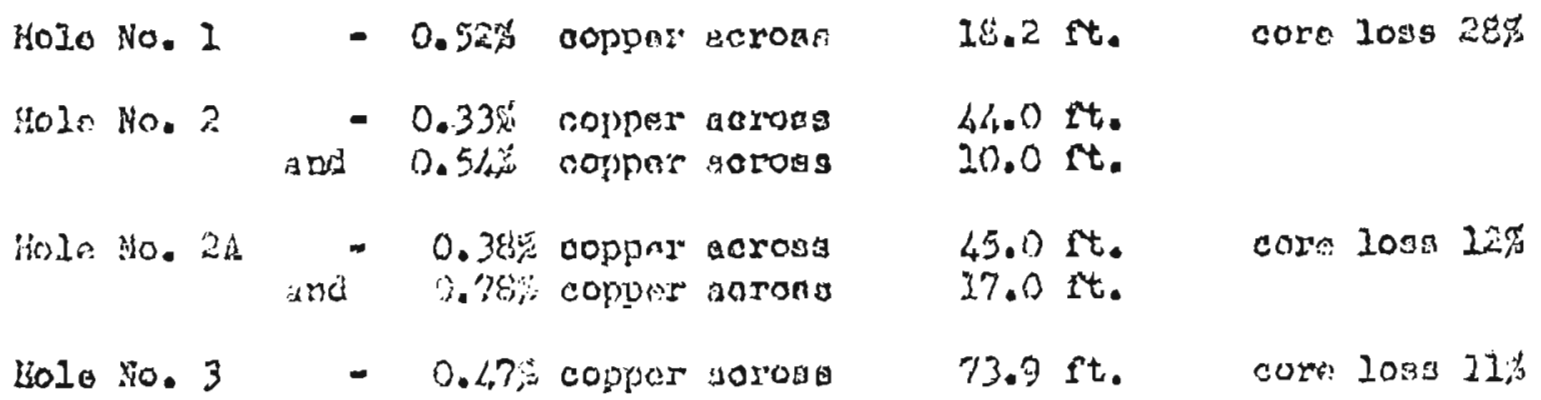

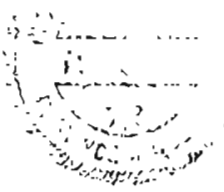




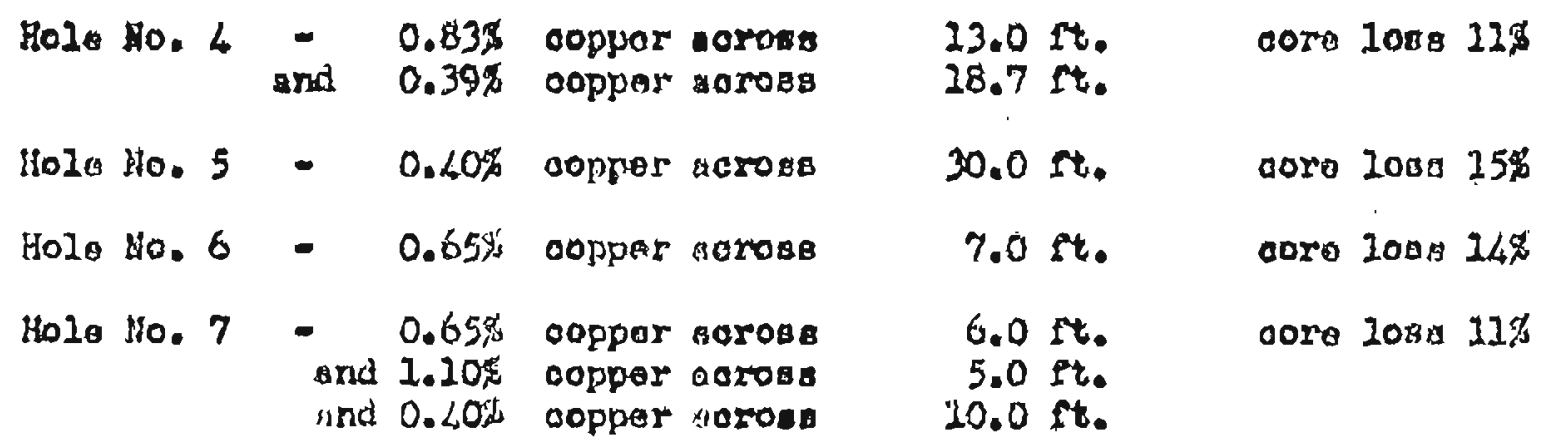

The abovo requits show copper over latoresting watbo, but in quentitsen that are aub-worgtanl to mine under opon the favourabin oonditions that oxist hore, Inoluding oponmout ming, aheap transportation and anooss. However, 1f the drill loge aro atudied and it 18 realized that 10 to $20 \%$ of tho minaralized cole was uround, thore gnomo to tha wreter room for doubto that these roulto acouratoly mpresent the coppe: contant in those inter ooctions.

Dowa to deptho of 200 feat tho feldnpurg arn kaolindzed and tho rook 1a shattarad snd saamed so that it is froe to sind in the core barrei

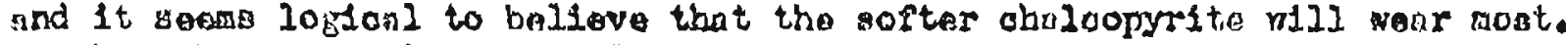
On the other hand sludge amplas do not show hlichor nopper vslues, but wh so rany gogme and foulte it 13 not cortain that all the honvy aulphidas rould to wohed to nurfidoe and ought. They mifht be trappod on thels ray up in open sroturas.

There senine a good ohanen that if more afflnient con reoovary

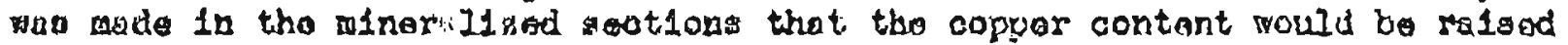
to oommeratal levele. ro this and it is oupgestod that holea be drillad to out the mineral1zod zonos uniar 200 foot vertsoally bejon tha wetharlag. and thet partioular onro be taken to prevont oopo loos by wrinding. Caro-

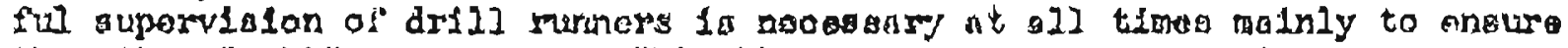
thut they "pull" as soon as a "blook" oocure and do not sont1nuo to mm and thus griad tho coro. This w11] antall a grogt das morn pork for thr orove, however, but it should give a truar platim of the amount of ooppor present.

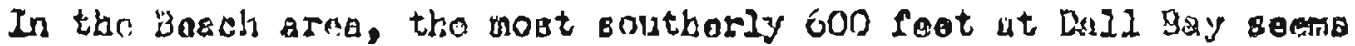
to ke tha pout prosalsine part of the property so par.

It is proposod that this leneth of 600 foet of altarad quirtz monzonite be drillad with" holes which rould intranget the known copyer bearing portion below the surfuoo neathoring. luch holn should have a

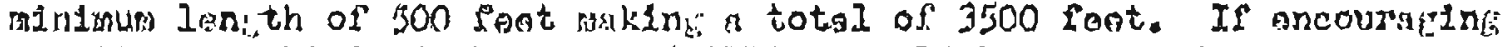
regulto are obtelawd then noris irliling would bo renulred. 


\section{Yorth Pulu Groyn - Seqd Gorax}

"CO" Pinlet LARE

\begin{tabular}{|c|c|c|c|c|c|c|c|c|c|}
\hline Hode $\mathrm{ke}, 26$ & & Dos & To & $\begin{array}{r}z \\
\text { gy }\end{array}$ & 雀卉h & $\begin{array}{l}\text { LoBt } \\
\text { Cors: }\end{array}$ & $\begin{array}{l}\text { DIp } \\
\text { Des. }\end{array}$ & $\begin{array}{c}\text { diz } \\
\text { Desco. }\end{array}$ & $\begin{array}{l}\text { Langth } \\
\text { Ftt }\end{array}$ \\
\hline plus 200 & 1251 & no 8 & ngs & & & & $45^{\circ}$ & $280^{\circ}$ & \\
\hline
\end{tabular}

Bole No, 16

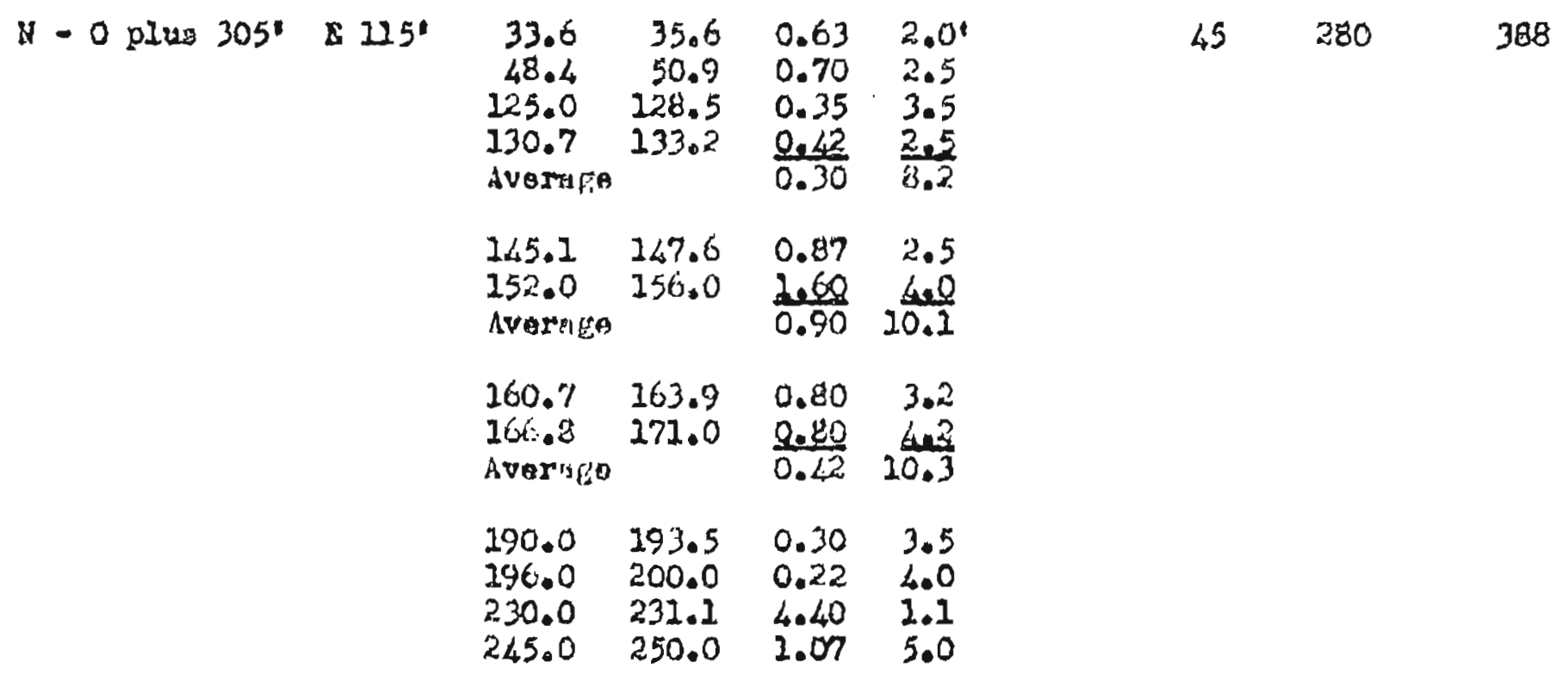

Hods 10.15

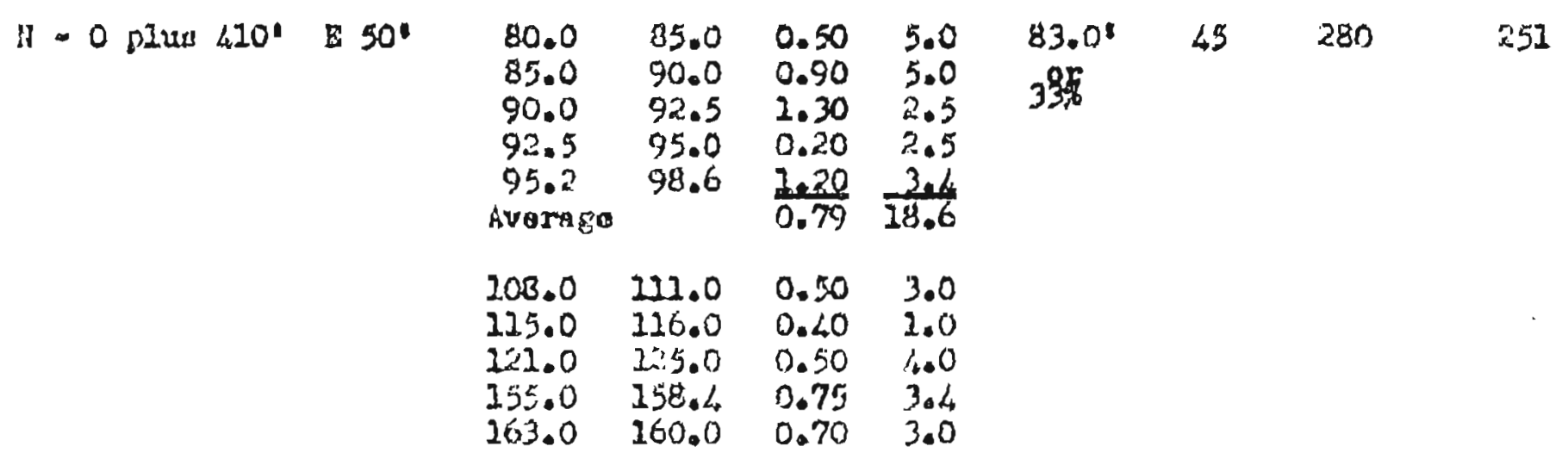

Holo 230.20

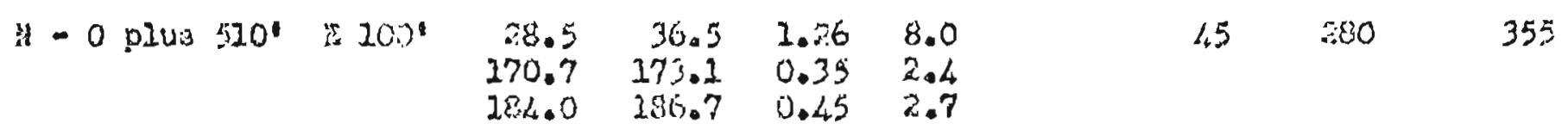


Bolo Ho. 22

N- O plue 710' \& 90'

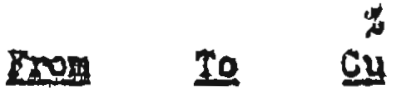

57.0 392.0

395.0 400.0 Avaraus
$59.3 \quad 0.30$

$$
395.0
$$

400.0

405.0

5.0

0.69

3.60

$\frac{0.45}{0.94} \quad \frac{5.0}{13.0}$

1X070 110.24

\& - O plus 7\%0 $\pi 5^{\prime} \quad 73.9 \quad 77.0 \quad 1.25 \quad 3.1$

TOPIL

$45 \quad 150$

$-360$ $2,153 \mathrm{ft}$.

"L" Pleket Won

Hole No, 22

3- 0 plus $40^{\circ}$ \& $85^{\circ}$ no a awpling

$45 \quad 250$

273

302010.27

* - 0 p

06.0

or

$16, \vec{*}$

HoL

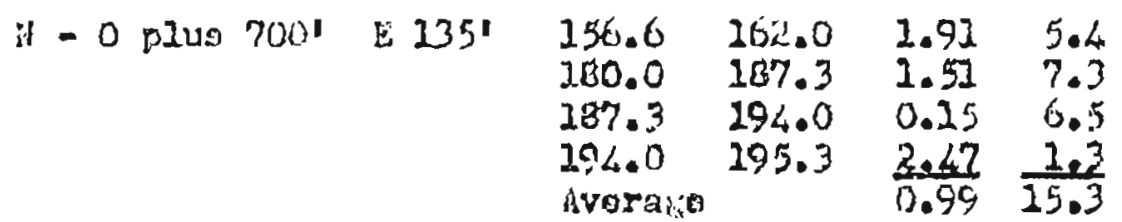

$50 \quad 250$

346

Hola Na, 23.

$\begin{array}{rrrrr}11 \text { - O gius } 870 \text { ii } 70^{\prime} & 40.0 & 42.0 & 1.88 & 2.0 \\ & 45.7 & 50.7 & 2.00 & 2.0 \\ & 134.3 & 242.7 & 1.76 & 8.4 \\ & 165.0 & 173.0 & 0.36 & 8.0\end{array}$

50

80

$21]$

I020 10123

$\forall$ - O plus 9901 is $751 \quad 129.8 \quad 131.0 \quad 2.00 \quad 1.2$

50

30

306

Hol 1 으, 22

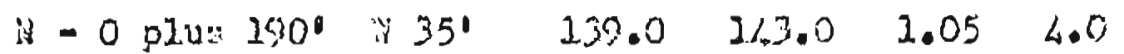

50

50

256 
"ge P1okst Lin

Holo No, 17

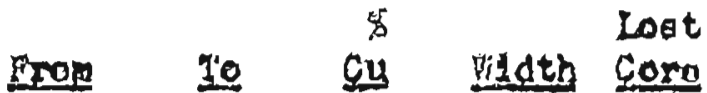

Dip is Iongth

$9-0$ plug $\pi 950$

60.070 .0

$0.42 \quad 20.01$

Dey. Dog.

Dt.

$9-0$ clus 795

$870^{\prime}$

$60.0 \quad 70.0$

500

991

Hole 150,18

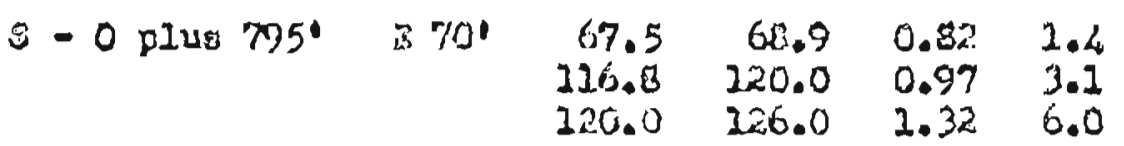

$65 \quad 250$

124

ronil -

$2235 t$.

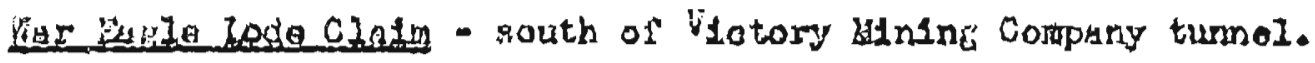

Bolo Blo 21

an agmpling

$45 \quad 310$

2174

4,430 faet.

The totul rootige drelled at the north end of the property mas

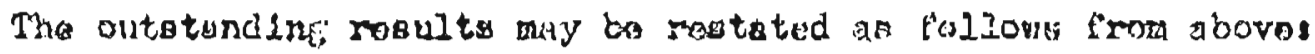

HCP" Ploket Ing

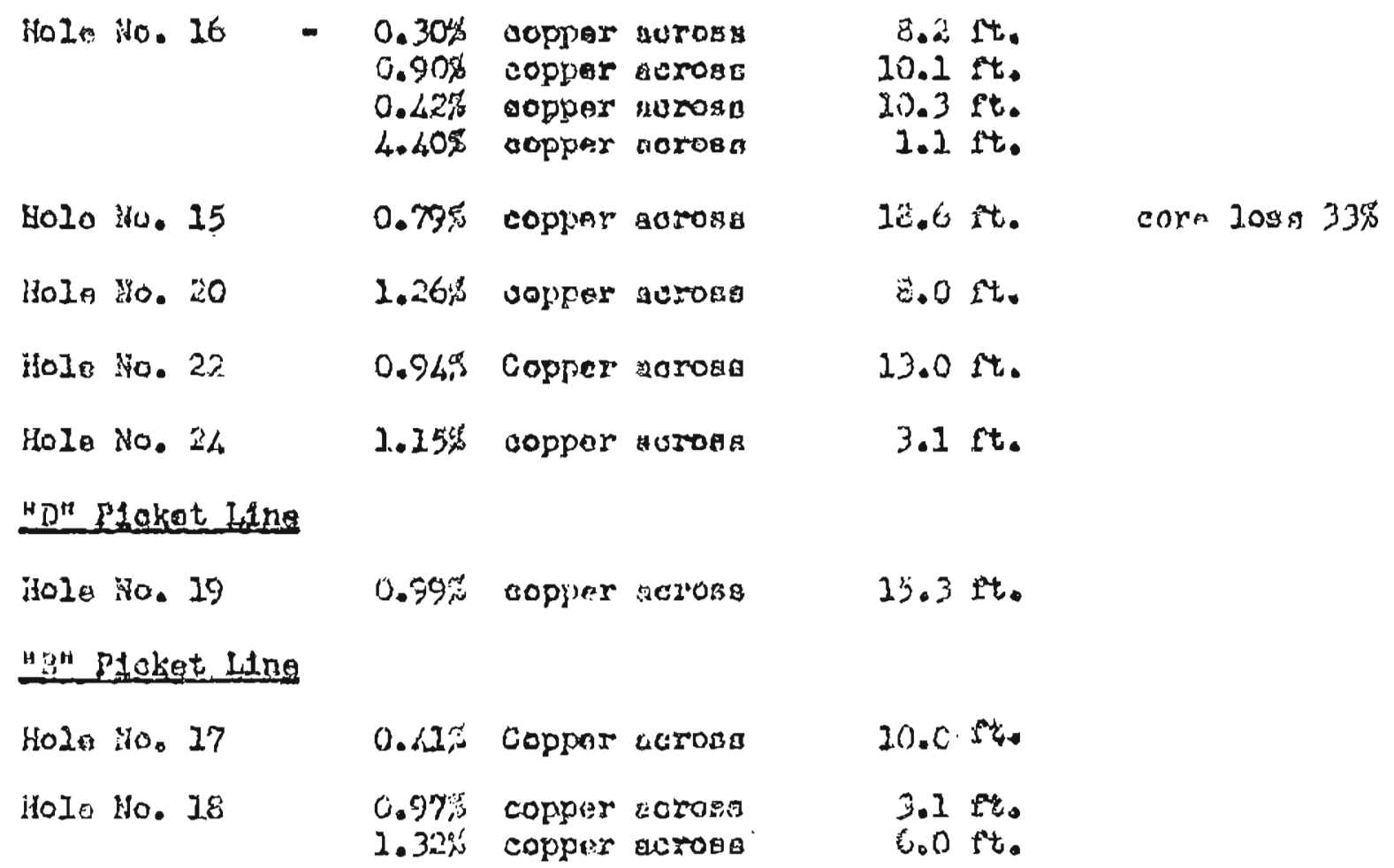




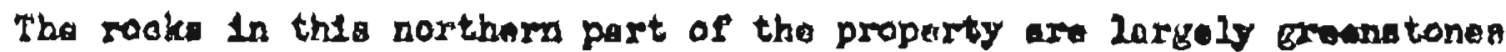

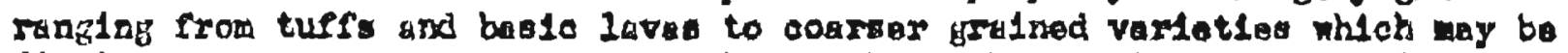
diortieg. They Inolude sediments also. Tho lightor coloured intrusires con

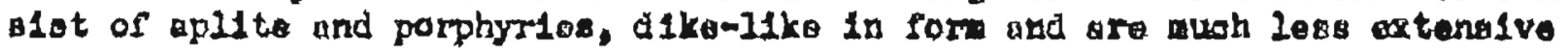
than the monoplto at Dull Bay. So is the alteretion, blenohing and the

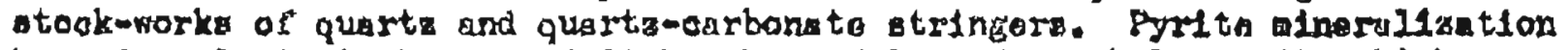

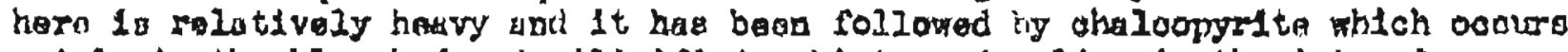

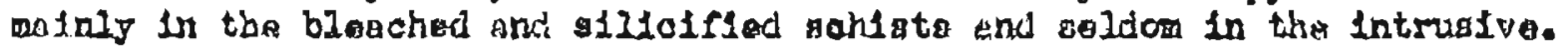

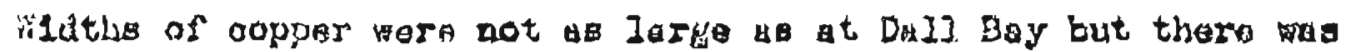

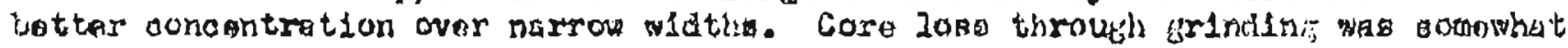

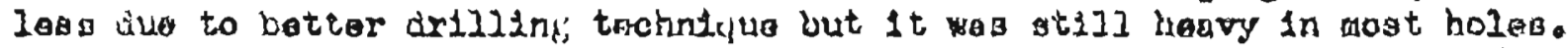

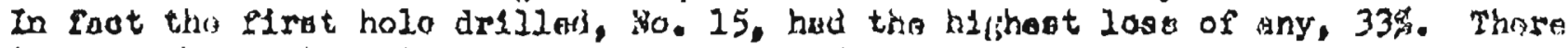
Is no doubt that an importent proportion of the oppper oontent rowlis be logt

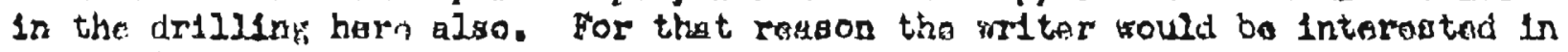

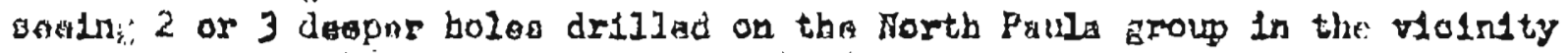
of holar 15 and 16 to cut the minorilsed aono below the offect of aurface

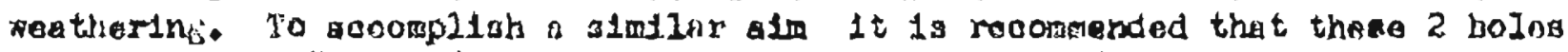
be doepened to 700 or 800 luet, If it 19 prootloal to 40 no. Thl gould

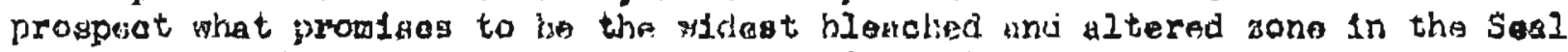
Cove araa. If Pavourablo results are cehleved then 1t my be onsicarad worth drilling additionel holes to both asat and weot is dell as to the nouth to complotaly axplore th1s favouretion zone. An unaxplored eup 11 a 200 seet to the couth of No. Io and 500 foet to the mest, millo the trat nat loon touchod.

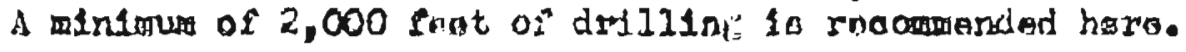

Dagesmant inork

On July lat, 1956, 4,123 font of diawond drililag was recorded on Palia Croup alina, No. I to 55, a total of 76 daye valuad at $39,000.00$. The remalndn 4,242 feet of drijisnis whould ba recordad on or bofore

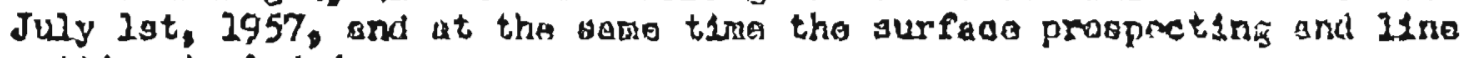
cutting 1nojuded.

Diamond drilIInis - 4,24I fout at is coot 36.65 per foot - $436,684.65$

Surfses proppoting and 1100 cuttinks 450 mon dags 317.75 -

$\frac{7.027 .50}{.44 .672 .15}$

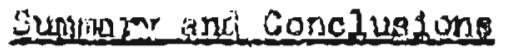

The coppex occurrences at Dals. Bny in the takch gros at the wouth end of the proparty ise cound in a brocelated and rracture band of rus rtz

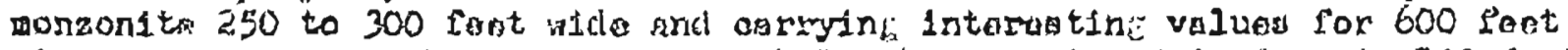
alon; ita north-south strika. 3aven holas have axplored 1t dom to son Inat vertically, althouigh thr inapost bole, Ho. 7, went to 270 fento

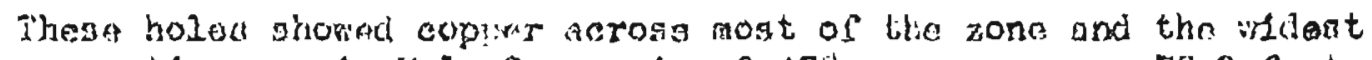

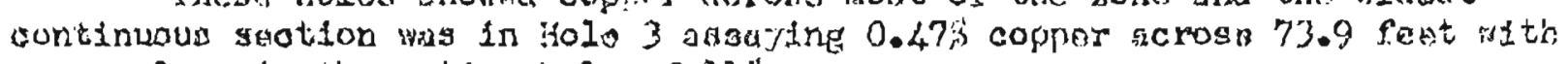
a cors 2008 in tha ontire hole of $11 \%$. 


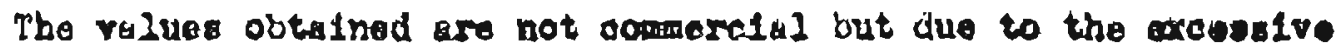

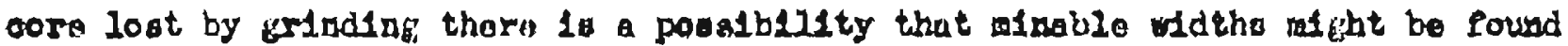
to srade over 15 copper if the 20 ne be out at suy 200 foet vert1cally bolow the

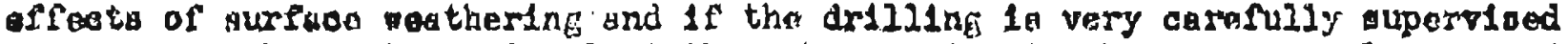

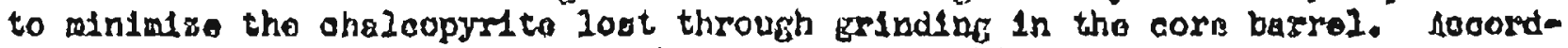
Ingly it is recomended that further testing of this zone be done next aumax by any 7 holes for a total of 3,500 sont.-

At the north ond of tho Panla group at SeQI Cove, somertust bettar coppor values occur aoross narrow w1dthe in quarta-aurbonato stook-works when the lavas have been blosebed and sliscliled. The laresst aros of altoration, around holo 15 and 16 hes not bnan oomplatoly axploriod and 2,000 foat of drillin, 1s

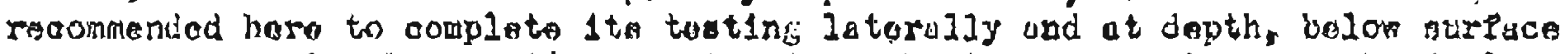
meathariak. Holos 15 and 16 oncountered the bast ooppar veluen In the seal Covn arga.

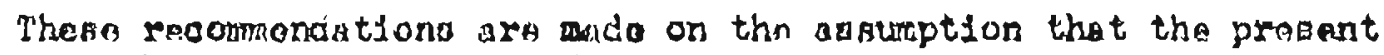
option way bo kopt in fore st no further cout to Bornite for the period of ope year frot now.

In oonelugion the withe rogard this property as an intareating

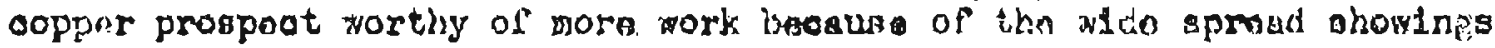

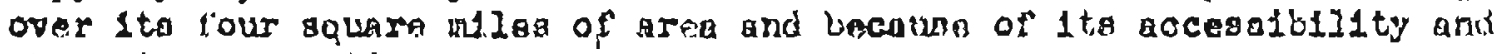
oboup trengportation.

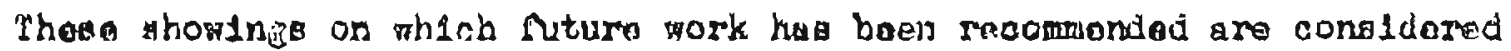
to ba the best found so far on the property.

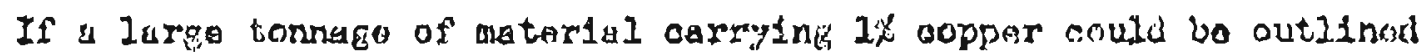

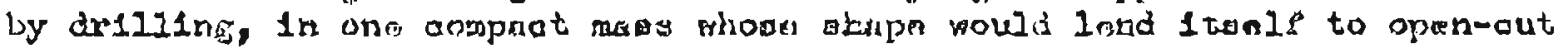
oining, thia prospoot oouid quickly dovelop into an 1oportant nins. Thar

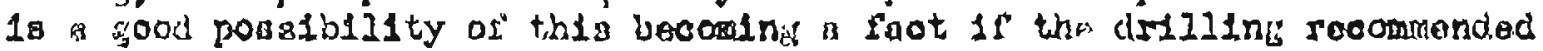

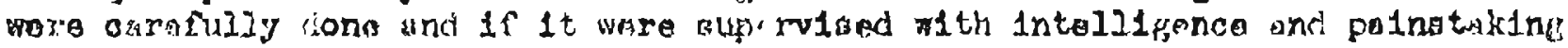
asm.

HOHiLIDa, LOUAO.

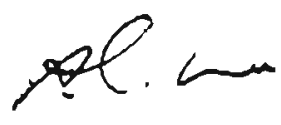

1Iun C. IAB,

irofoetongl intineor.

Provinose of ueboc.

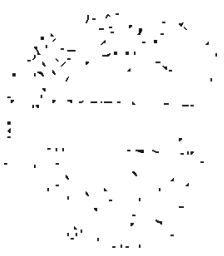




\section{Dornt to Copper Corporation Laltod \\ LaRolno and Des melolyos Tomnahips \\ Horthregters qubec}

Roverbar 13,2956

This proporty has boan fully dosordbed in ry provious report dated Docemicar 12, 195\%, as to proporty, location and alain numbars. A later roport of lay 22, 1956, deecribes tho

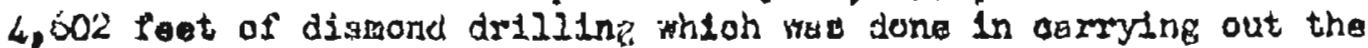
recourondetions of the earliar roport.

Sinoe tho repulta of this rexo inconolualva no further mork hus been done on the property up to the prosont date.

HOStitidA, quebeo.

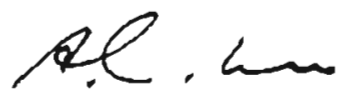

nlan C. LaO, Profesatonal ginger, Provino of 'juphec. 


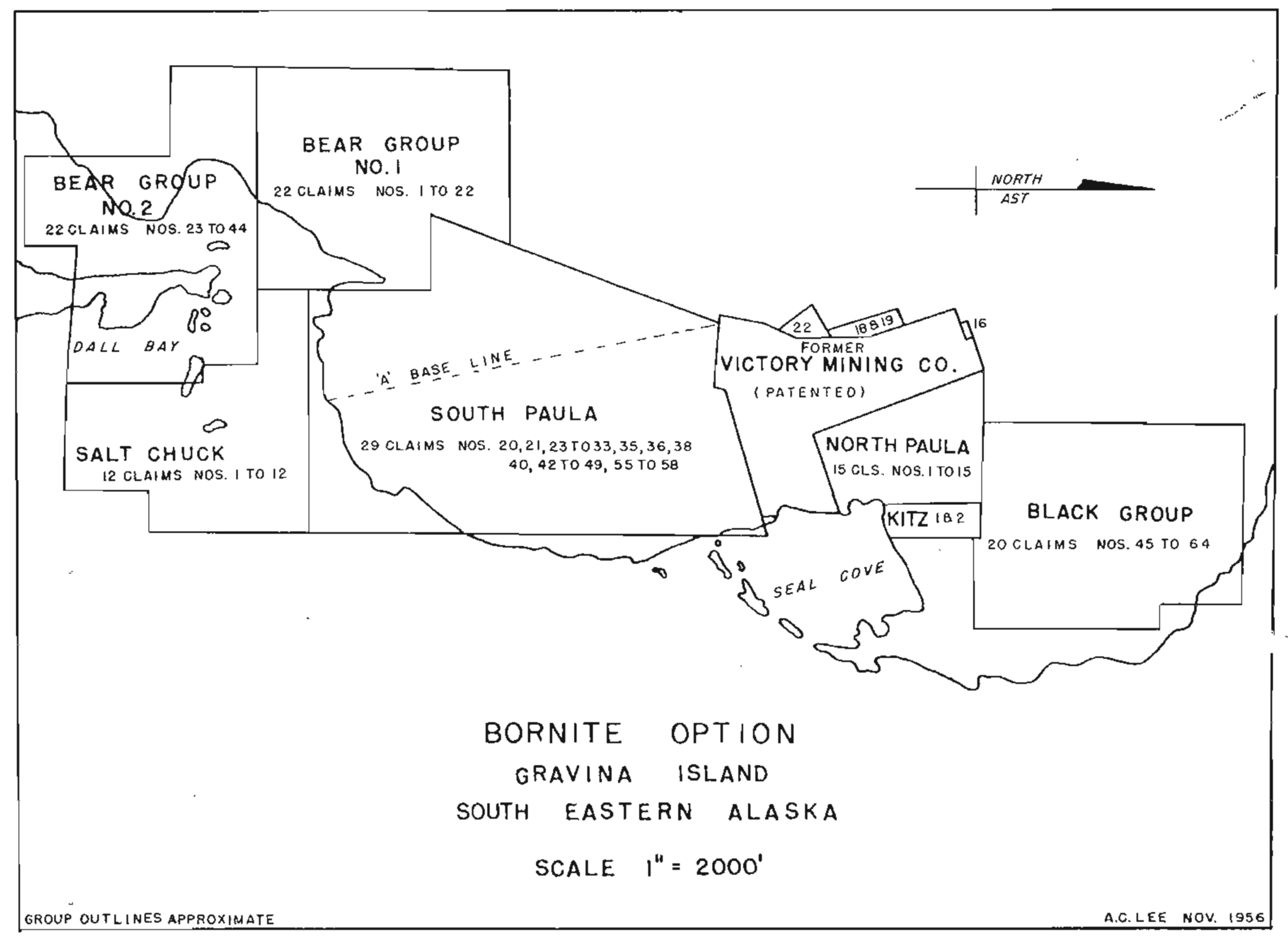

